\title{
Introduction of Asian Soybean Rust Urediniospores into the Midwestern United States-A Case Study
}

\author{
Sagar Krupa, Department of Plant Pathology, University of Minnesota, St. Paul 55108; Van Bowersox and Roger \\ Claybrooke, Illinois State Water Survey, National Atmospheric Deposition Program \& National Trends Network \\ (NADP \& NTN) Programs, Champaign, IL 61820; Charles W. Barnes and Les Szabo, United States Department of \\ Agriculture-Agricultural Research Service, Cereal Disease Laboratory, St. Paul, MN 55108; Karen Harlin, Illinois \\ State Water Survey, NADP \& NTN Programs, Champaign; and James Kurle, Department of Plant Pathology, Uni- \\ versity of Minnesota, St. Paul
}

\begin{abstract}
Krupa, S., Bowersox, V., Claybrooke, R., Barnes, C. W., Szabo, L., Harlin, K., and Kurle, J. 2006. Introduction of Asian soybean rust urediniospores into the midwestern United States-a case study. Plant Dis. 90:1254-1259.

In 2005, weekly rain samples collected at 124 National Atmospheric Deposition Program/National Trends Network (NADP/NTN) sites in the eastern and central United States were screened for Asian soybean rust (ASR; Phakopsora pachyrhizi) urediniospores. Application of a quantitative polymerase chain reaction method detected $P$. pachyrhizi DNA in the filter residue of rain samples collected during the week of 19 to 26 July 2005 in Minnesota, Missouri, and South Dakota. To determine the geographic origin of ASR urediniospores in those weekly composite samples, back air trajectories of the lifted condensation and mixed boundary layers were calculated for each rain event within the week, by sampling site. The calculations, based on the hybrid single-particle lagrangian integrated trajectory model, pointed to source areas in eastern and southern Texas. In a separate case, DNA of P. pachyrhizi was detected in a 28 June to 5 July 2005 rain sample from an eastern Texas site. Back trajectories pointed to southern Texas and the Yucatan Peninsula in Mexico as potential source areas of ASR urediniospores. Vertical motions of those back trajectories indicated a ventilation of the boundary layer in the upwind areas, suggesting the possible injection of urediniospores into the free troposphere where they can be transported for long distances before wet deposition.
\end{abstract}

Additional keywords: spore transport

For the first time, Asian soybean rust (ASR) disease caused by Phakopsora pachyrhizi Sydow was reported in the continental United States during 2004 (30). Similar observations also were made in 2005. P. pachyrhizi is an obligate fungal parasite that produces both uredinia and telia in controlled environments, under proper conditions (15). However, the alternate host (aecial) is unknown and, therefore, little is known about the role of the telial stage in the life cycle of the fungus in nature and the rust is thought to rely exclusively on continuous production of urediniospores on a living host for its survival (25). Spore dispersal and disease spread is a function of aerial dissemination of ured-

Corresponding author: J. Kurle

E-mail: kurle001@umn.edu

Any findings or conclusions stated in this publication do not necessarily reflect the views of the United States Department of Agriculture or other sponsors.

Accepted for publication 10 April 2006.

DOI: 10.1094/PD-90-1254

(C) 2006 The American Phytopathological Society iniospores from infected plants. ASR is most likely to survive typical winters in the continental United States by persisting on annual and perennial alternative hosts in southernmost Texas and Florida, coastal areas of the Gulf States, and southern California. $P$. pachyrhizi has a wide host range in the legume family that includes soybean, dry and snap bean, pea, and a number of forage crops (e.g., sweet clover) and weeds (e.g., kudzu) (24). Thus, south to north aerial dispersal of urediniospores from infected hosts will determine whether the rust can occur in the principal soybeangrowing areas of the north-central United States. Source regions of the fungal inoculum will be at large distances from the major soybean-growing areas of the upper Midwest; therefore, long-range transport and deposition of viable urediniospores will be an important mechanism for annual reintroduction of ASR. Experience with disease incidence surveys for the rusts of corn and small grains indicates that urediniospores from infected plants in Mexico, southern Texas, and Louisiana routinely contribute to development of epidemics in the north-central United States $(28,29)$.

Soybean rust urediniospores are coarse particles (about 18 to 34 by 15 to $24 \mu \mathrm{m}$ in size) that obey the laws of gravity or rapid sedimentation or settling to the surface once released into the atmosphere. Thus, they cannot travel long distances close to the surface, within the mixed boundary layer (MBL; the atmosphere influenced by surface heat exchange and turbulent mixing). On the other hand, they can travel long distances once transported upward above the variable MBL height into the free troposphere (FT), where there is minimal resistance for horizontal transport. Once in the FT at large distances from the initial source regions, rain is a major mechanism for depositing coarse particles, including fungal spores, onto the surface (23). For example, Krupa et al. (13) and Krupa and Nosal (14) showed the importance of summertime anticyclonic or clockwise motion of air parcels preceding the wet deposition (precipitation) of high concentrations of air pollutants (e.g., particulate sulfate and nitrate) by long-range transport across the central plains into Minnesota.

Although the details of the specific methodologies used for the identification of ASR urediniospores will be reported elsewhere, the main objective of the present case study was to examine the potential for the atmospheric transport of soybean rust urediniospores across the central plains into the Midwest and for its spread from the southern to the northern United States through wet deposition.

\section{MATERIALS AND METHODS}

Rain sample collection and sample preparation. At some 124 sites in the eastern and central United States, weekly, composite rain samples were collected according to the NADP/NTN (National Atmospheric Deposition Program/National Trends Network) protocol for precipitation sampling (4). The times of occurrence (dates and hours) and depths of individual rain events contributing to the weekly composite samples were obtained independently using chart data from recording, co-located rain gages. After measuring the $\mathrm{pH}$ and electrical conductance of the rain samples in the laboratory for atmospheric deposition and climate-related studies, they were vacuum filtered. The filters were 
desiccated in clean air and subsequently analyzed for the presence of $P$. pachyrhizi DNA.

Identification of soybean rust urediniospores. Rain sample filter residues were extracted for DNA and analyzed through the application of a nested quantitative polymerase chain reaction (qPCR; modified from the PCR procedure of Frederick et al.; 8) assay using a $P$. pachyrhizispecific Taqman probe (C. W. Barnes and L. Szabo, United States Department of Agriculture-Agricultural Research Service, Cereal Disease Laboratory, St. Paul, $\mathrm{MN}$, unpublished data). Where appropriate, the qPCR results were confirmed by gel electrophoresis for the presence of DNA amplification product corresponding to the predicted size for $P$. pachyrhizi. In addition, DNA sequence analysis of selected samples was used to further confirm the specificity of the qPCR assay (C. W. Barnes and L. Szabo, unpublished data).

Application of an atmospheric particle or spore transport model. For the rain sampling sites and dates listed in Table 1, back air trajectory analyses were performed using the hybrid single-particle lagrangian integrated trajectory (HYSPLIT) model (6) to identify potential ASR source areas and spore transport pathways. The HYSPLIT model was initialized using meteorological data from the National Weather Service's Eta model. The domain of these data sets the domain limits of HYSPLIT trajectories (21). For each rain event, trajectories were initiated at two heights above the surface and calculated for up to $168 \mathrm{~h}$ prior to the event. Those heights were the MBL and the lifting condensation layer (LCL) or the cloud layer at the time of the rain event. The MBL and LCL heights were determined from analysis of National Weather Service atmospheric soundings nearest in time and space to each rain event recorded at the NADP/NTN site. The HYSPLIT model computes the location and height of back trajectories. Vertical wind displacements were used to identify areas of possible injection of rust urediniospores into the FT, where the urediniospores could be transported long distances before deposition. Identifying these injection points required determination of the MBL heights from atmospheric soundings along the backward (i.e., upwind) trajectory pathways. Urediniospores may enter the FT when the trajectory rises from beneath the MBL height into the FT.

\section{RESULTS AND DISCUSSION}

A summary of the data set used for the trajectory analysis is provided in Table 1 . For this case study, only samples where the presence of ASR urediniospores (DNA) was identified by more than one independent analytical method were used. Because weekly NADP/NTN samples frequently contain more than one rain event, as noted previously, the trajectory analyses were performed for individual events, with such information derived from the recording rain gage co-located with the rain sampler.

Sample from the LBJ Grasslands site. Filter residue of the weekly rain sample collected at the LBJ Grasslands site
(TX56; latitude: $33.3917 \mathrm{~N}$, longitude: $97.6397 \mathrm{~W}$ ) during 28 June to 5 July 2005 tested positive for the presence of ASR urediniospores (DNA). This sample contained rainfall from two events: (i) 0.05 $\mathrm{cm}, 1200$ to $1300 \mathrm{Zulu}$ Time (i.e., $12 \mathrm{Z}$ to

Table 1. Summary data on rain sample collection and identification of soybean rust DNA ${ }^{\mathrm{a}}$

\begin{tabular}{|c|c|c|c|c|c|}
\hline $\begin{array}{l}\text { NADP } \\
\text { site ID }\end{array}$ & Site name, state & $\begin{array}{c}\text { Rain sampling } \\
\text { period }\end{array}$ & $\mathbf{q P C R}$ & $\begin{array}{c}\text { Gel } \\
\text { electrophoresis }\end{array}$ & $\begin{array}{c}\text { DNA } \\
\text { sequence }\end{array}$ \\
\hline TX56 & LBJ Grasslands, Texas & 28 June to 5 July & + & + & $\mathrm{Nd}$ \\
\hline MO03 & Ashland Wildlife, Missouri & 19 July to 26 July & + & + & $\mathrm{Nd}$ \\
\hline SD08 & Cottonwood, South Dakota & 19 July to 26 July & + & + & $\mathrm{Nd}$ \\
\hline MN27 & Lamberton, Minnesota & 19 July to 26 July & + & + & + \\
\hline
\end{tabular}

${ }^{a}$ Analysis was performed on composite rain samples collected during the week; $+=$ positive result and $\mathrm{Nd}=$ not done.

b NADP = National Atmospheric Deposition Program sites (19).

${ }^{\mathrm{c}} \mathrm{qPCR}=$ quantitative polymerase chain reaction.
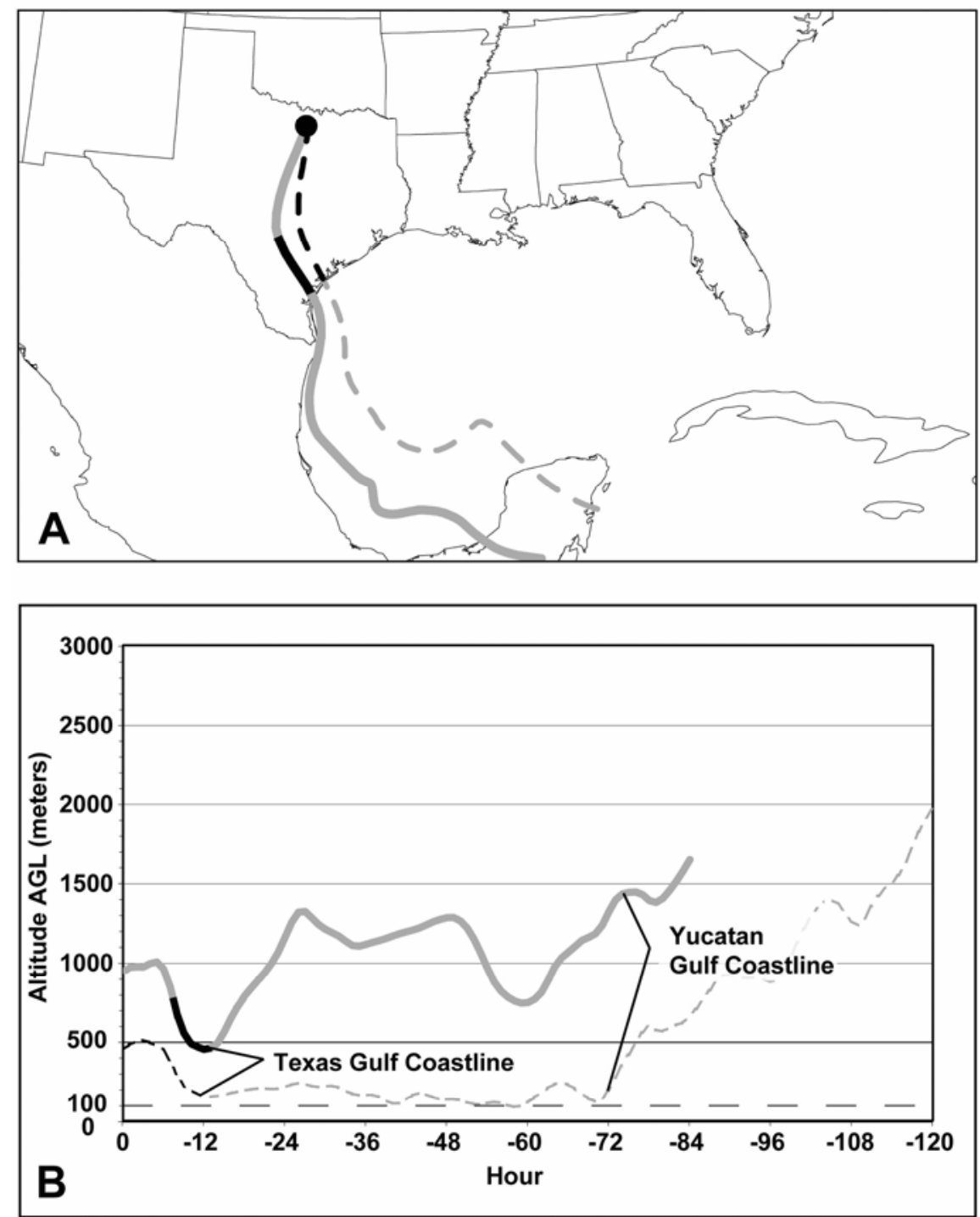

Fig. 1. Hybrid single-particle lagrangian integrated trajectory (HYSPLIT) back trajectories for the 4 July 2005 rain event at the LBJ Grasslands National Atmospheric Deposition Program/National Trends Network site (TX56). Solid line marks the trajectory initiated at the lifting condensation layer height $(938 \mathrm{~m})$ and dashed line marks the trajectory initiated at the mixed boundary layer height $(453 \mathrm{~m})$ at 1200 Zulu Time (12Z), 4 July 2005. Black line segments indicate potential Asian soybean rust source areas. A, Surface locations of back trajectories, with the shaded area depicting trajectory variability (see text). The trajectories were terminated near the southern limits of HYSPLIT model output. B, Vertical locations of back trajectories in meters above ground level (AGL). The $\mathrm{X}$ axis indicates the number of hours backward in time from 12Z, 4 July 2005. 
13Z), 4 July and (i) $0.03 \mathrm{~cm}, 01 \mathrm{Z}$ to $03 \mathrm{Z}, 5$ July. HYSPLIT back trajectories were initiated at LCL and MBL heights for each event. These heights were determined from atmospheric soundings at the Fort Worth, TX upper-air station, less than two model grid squares (grid square $=40$ by $40 \mathrm{~km}$ ) from the LBJ Grasslands site.

On 4 July, both LCL and MBL back trajectories arriving at TX56 (Fig. 1A) followed a transport pathway that crossed the Yucatan Peninsula (YP) and the Gulf of Mexico before entering southeastern Texas. These back trajectories were terminated near the southern domain limits of HYSPLIT model output. The shaded area in Figure 1 identifies the spatial variability of these trajectories and was determined from the ensemble form of the HYSPLIT, which generates a set of trajectories by letting the initial meteorological conditions vary slightly (5). The results showed that LCL and MBL ensembles virtually occupied the same area or domain. The HYSPLIT-modeled vertical movements of the trajectories are shown in Figure 1B. After descending into the boundary layer over the YP, the lower trajectory remained in the boundary layer across the Gulf of Mexico and much of Texas before it rose to the upper bound of the MBL height at the LBJ Grasslands site. The upper trajectory (Fig. 1B) rose further upward from the MBL into the FT in southeastern Texas at about $12 \mathrm{~h}$ prior to the rain event. Urediniospores from ASR-infected plants may have entered the FT in this area and may have been transported to and subse-
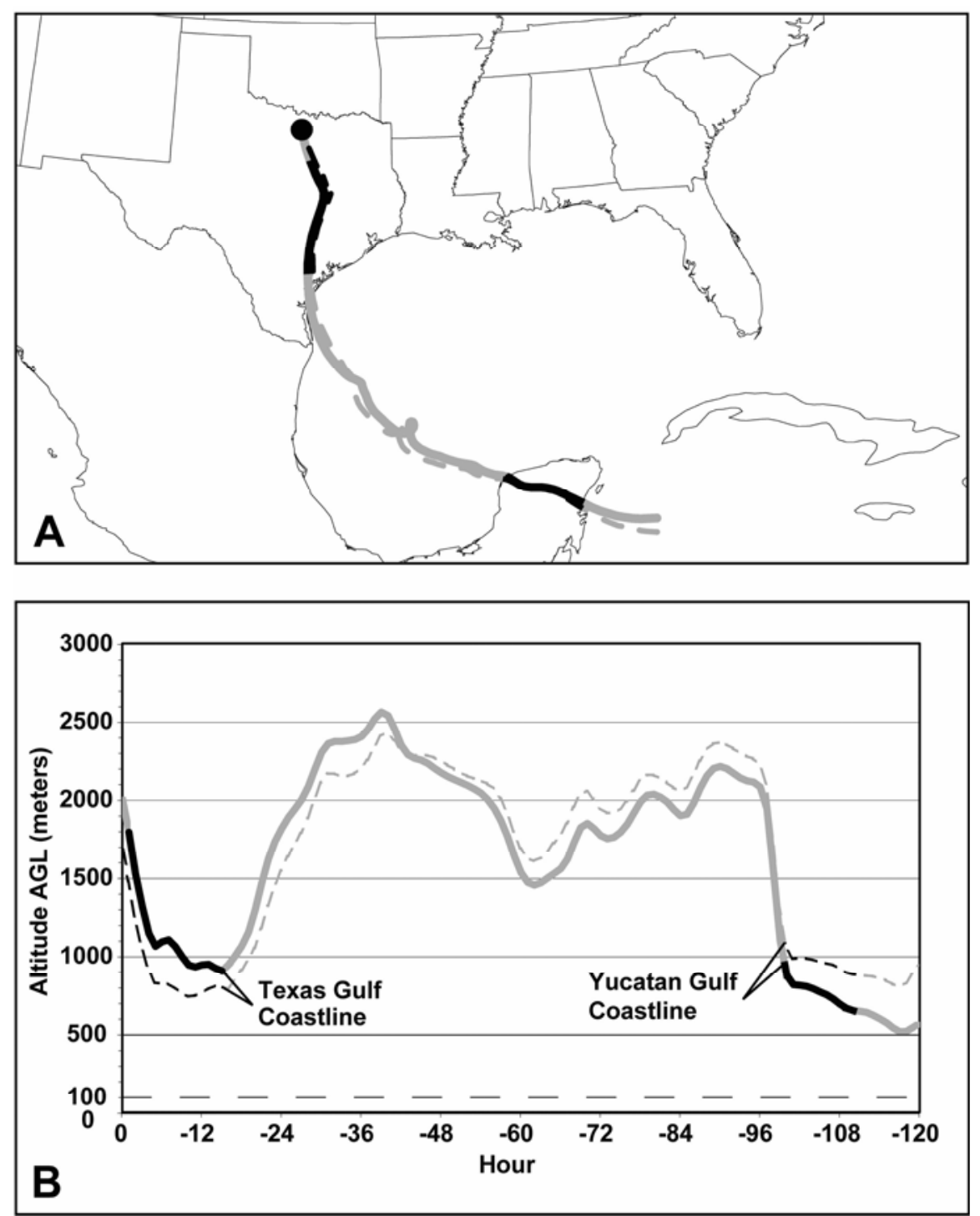

Fig. 2. Hybrid single-particle lagrangian integrated trajectory (HYSPLIT) back trajectories for the 5 July 2005 rain event at the LBJ Grasslands National Atmospheric Deposition Program/National Trends Network site (TX56). Solid line marks the trajectory initiated at the lifting condensation layer height $(2,008 \mathrm{~m})$ and dashed line marks the trajectory initiated at the mixed boundary layer height $(1,688 \mathrm{~m})$ at 0200 Zulu Time (02Z), 5 July 2005. Black line segments indicate potential Asian soybean rust source areas. A, Surface locations of back trajectories, with the shaded area depicting trajectory variability (see text). The trajectories were terminated near the southern limits of HYSPLIT model output. B, Vertical locations of back trajectories in meters above ground level (AGL). The $\mathrm{X}$ axis indicates the number of hours backward in time from 02 Z, 5 July 2005.

quently deposited by rain at the TX56 NADP/NTN site on 4 July. ASR disease subsequently was reported from Liberty County in southeastern Texas on 2 November 2005 (11).

For the 5 July event, the back trajectories showed overland and overwater pathways that were very similar in location to the 4 July event (compare Figs. 1A and 2A). However, in this case, meteorological conditions for venting spores from the MBL into the FT existed not only in southeastern Texas but also over the YP (Fig. 2B) at about 96 to $108 \mathrm{~h}$ prior to the rain event at TX56. This suggests that the YP also may be an ASR source region for urediniospores vented into the FT, transported long distances, and deposited in the continental United States. Mims and Mims (17) found viable spores of a number of fungi in smoke transported into southcentral Texas from biomass fires in YP. However, to our knowledge, ASR disease has not been reported in the YP and, thus, that geographic region warrants future attention, particularly regarding the importance of its alternative hosts as sources of ASR inoculum. Recently, ASR has been found in Mexico on soybean in regions north of YP (in Tamuin, State of San Luis Potosi, and in Altamira, State of Tamaulipas, where the back trajectory traversing across the Gulf of Mexico from YP actually reached the land surface; Fig. 1A).

Sample from the Ashland Wildlife site. ASR spores (DNA) were detected in the $1.0-\mathrm{cm}$ rain event that occurred at $23 \mathrm{Z}$ to $24 \mathrm{Z}$ on 23 July at the Ashland Wildlife site (MO03; latitude: $38.7536 \mathrm{~N}$, longitude: $92.1989 \mathrm{~W}$; Table 1). This was the only rainfall recorded during the 19 to 26 July sampling period at that site. The closest National Weather Service upper-air station to the Ashland Wildlife site (Springfield, MO) is more than four model grid squares away; therefore, the LCL and MBL heights for this rain event were calculated as an inverse distance weighted average of the five surrounding upper-air stations. The trajectory initiated at the LCL (Fig. 3) spiraled westward, crossing parts of Missouri, Kansas, Nebraska, and Wyoming. Throughout its pathway, this trajectory remained above the boundary layer and generally $2,000 \mathrm{~m}$ or more above ground level (AGL). Display of the LCL trajectory (Fig. 3) was terminated in mountainous central Wyoming. This cloud-level trajectory crossed important soybeangrowing areas east of the Rocky Mountains in the midwestern United States, although ASR disease has not been reported from these areas. By contrast, the lower MBL trajectory originated southwest of the site. Its pathway was largely within the boundary layer through Kansas, Oklahoma, and central Texas. This trajectory was terminated where its modeled elevation fell below $50 \mathrm{~m}$ in east-central Texas. As mentioned previously, ASR was re- 
ported in Liberty County, TX, where it was found on kudzu. Overall, these observations suggest that the lower air mass provided the rust spores scavenged by the rain event of 23 July at the MO03 site. Nevertheless, one cannot completely rule out infected alternative hosts to the northwest of the site or intercontinental transport of fungal (ASR) spores $(10,26)$.

Sample from the Cottonwood site. The weekly NADP/NTN sample collected during 19 to 26 July at the Cottonwood, SD site (SD08; latitude: $43.9461 \mathrm{~N}$, longitude: $101.8552 \mathrm{~W}$ ) proved positive for ASR spores (DNA; Table 1). This sample contained rainfall from four events: (i) $0.38 \mathrm{~cm}, 02 Z$ to $04 Z, 22$ July; (ii) $2.29 \mathrm{~cm}$, $05 \mathrm{Z}$ to $09 \mathrm{Z}, 24 \mathrm{July}$; (iii) $0.13 \mathrm{~cm}, 18 \mathrm{Z}$ to 20Z, 25 July; and (iv) $0.10 \mathrm{~cm}, 10 Z$ to 13Z, 26 July. HYSPLIT back trajectories were initiated at LCL and MBL heights for each event. These heights were determined from atmospheric soundings at the Rapid City, SD upper-air station, approximately two model grid squares from the Cottonwood site. Air trajectories for the events of 22, 24, and 26 July (Fig. 4A) generally were from the west and northwest, which are not likely ASR source areas. In contrast, the LCL and MBL trajectories preceding the rain event of 25 July (Fig. 4B) entered the MBL over potential source areas in southern Mississippi, central Louisiana, and northern and east-central Texas. In addition to the previously mentioned report of ASR in Liberty County, TX, it also was reported on soybean in George County, in southern Mississippi, on 13 July

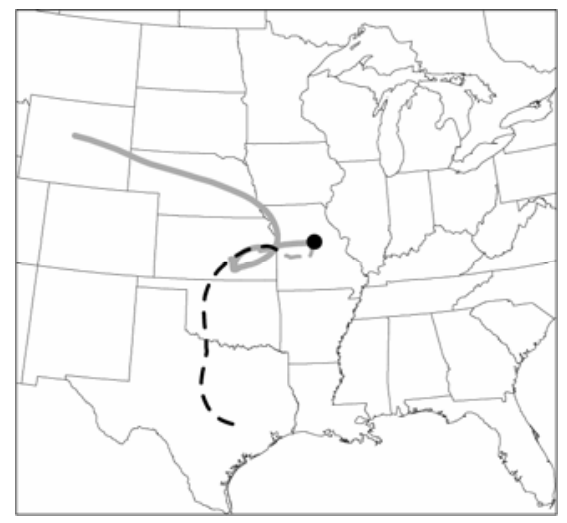

Fig. 3. Hybrid single-particle lagrangian integrated trajectory back trajectories for the 23 July 2005 rain event at the Ashland Wildlife National Atmospheric Deposition Program/National Trends Network site (MO03). Solid line marks the trajectory initiated at the lifting condensation layer (LCL) height $(1,929 \mathrm{~m})$ and dashed line marks the trajectory initiated at the mixed boundary layer (MBL) height $(1,050 \mathrm{~m})$ at 2300 Zulu Time, 23 July 2005. Black line segments indicate potential Asian soybean rust source areas. Display of the back trajectory from the LCL height was terminated at $97 \mathrm{~h}$, where it entered a mostly mountainous region. Display of the back trajectory from the MBL height was terminated where the modeled elevation fell below $50 \mathrm{~m}$ above ground level (AGL).
2005; on soybean in a sentinel plot in Pearl County, in southern Mississippi, on $5 \mathrm{Au}-$ gust, on soybean in east Baton Rouge Parrish, LA (28 October), and on kudzu in Tangipahoa Parrish, LA (18 November) (31). To date, the disease has not been reported in northern Texas, northeastern New Mexico, or east-central Nebraska, where the trajectories also entered the MBL (Fig. 4B).

Sample from the Lamberton site. ASR spores (DNA) also were detected at Lamberton, MN (MN 27; latitude: $44.2372 \mathrm{~N}$, longitude: $95.3006 \mathrm{~W})$ during 19 to 26 July 2005 (Table 1). The sample was a composite of a $0.89-\mathrm{cm}$ rainfall that occurred from $0.8 \mathrm{Z}$ to $11 \mathrm{Z}, 20 \mathrm{July}$, and a $3.18-\mathrm{cm}$ rainfall from $20 \mathrm{Z}, 25$ July to 0.1 Z, 26 July. The closest National Weather Service upper-air station to the Lamberton
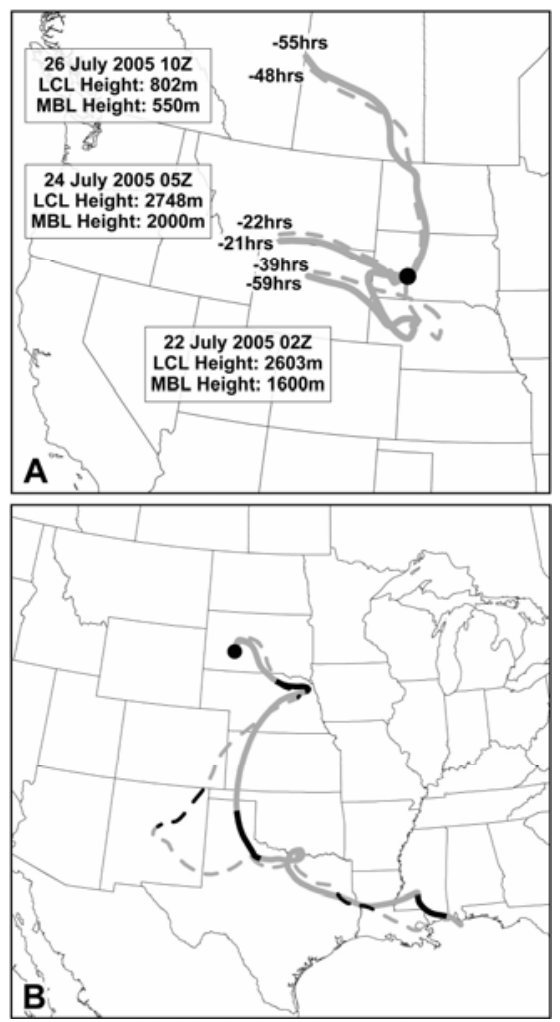

Fig. 4. Hybrid single-particle lagrangian integrated trajectory back trajectories for the four rain events at the Cottonwood National Atmospheric Deposition Program/National Trends Network site (SD08) during the 19 to 26 July 2005 sampling period. A, Back trajectories for the events of 22,24 , and 26 July 2005 . Solid lines mark the trajectories initiated at the lifting condensation layer (LCL) height and dashed lines the trajectories initiated at the mixed boundary layer (MBL) heights, as labeled in the figure. The displays of these trajectories were terminated at the times indicated, because the pathways likely did not cross Asian soybean rust (ASR) spore source areas. B, Back trajectory for the 25 July 2005 event. The solid line marks the trajectory initiated at the LCL height $(1,354 \mathrm{~m})$ and the dashed line marks the trajectory initiated at the MBL height $(1,100 \mathrm{~m})$ at $1800 \mathrm{Zulu}$ Time, 25 July 2005. Black line segments indicate potential ASR source areas. site (Aberdeen, SD) is more than seven model grid squares away; therefore, the LCL and MBL heights for these rain events were calculated as inverse distance weighted averages of five surrounding upper-air stations. Back trajectories (Fig. 5) showed that LCL and MBL air masses moved generally from south to north for both events. All four trajectories were terminated where modeled elevations fell below $50 \mathrm{~m}$ AGL. Areas where spores may have entered these air parcels (Fig. 5, black line segments) were determined by comparing the vertical movements of the air parcels with MBL depths upwind of the rain events. Among the areas where the parcels entered the MBL and may have picked up spores was east-central Texas (MBL trajectory, 20 July event), generally the same source region for both the Missouri and South Dakota events (Figs. 3 and 4).

Strong thermal heating or high wind conditions provide the turbulent energy to carry the coarse particles or spores above the boundary layer $(\geq 1$ to $2.5 \mathrm{~km}$ above ground) into the FT where they can be transported hundreds or even thousands of kilometers before they are removed by deposition processes (dry and wet; 7,26). The dry deposition flux is greatest close to the source, where the coarse particle or spore concentration is highest, and it decreases with distance from the source as the spores are dispersed. As the distance from the spore-generating source grows, dry deposition becomes much less important.

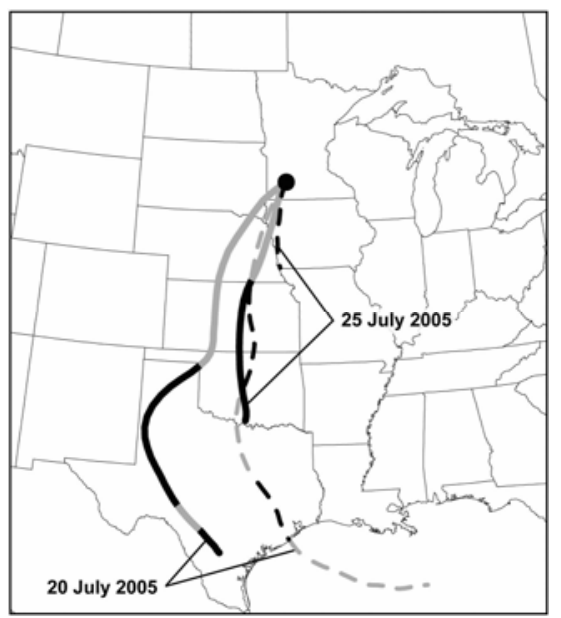

Fig. 5. Hybrid single-particle lagrangian integrated trajectory back trajectories for the two rain events at the Lamberton National Atmospheric Deposition Program/National Trends Network site (MN27) during the 19 to 26 July 2005 sampling period. Solid line marks the trajectory initiated at the lifting condensation layer height (1,085 m., 20 July event and 1,072 m., 25 July event) and dashed line marks the trajectory initiated at the mixed boundary layer height $(700 \mathrm{~m}$., both events). Black line segments indicate potential Asian soybean rust source areas. Back trajectory displays were terminated where modeled elevations fell below $50 \mathrm{~m}$ above ground level. 
At large distances from the source, precipitation is the dominant mechanism for coarse particle or spore deposition (23). The predominant storm type is convective by nature throughout much of the growing season in the continental United States (3). Convective storm formation provides a convergence mechanism for concentrating the dispersed coarse particles or spores and capturing them in cloud droplets and raindrops (23).

A number of investigators have shown long-range atmospheric transport of fungal spores $(1,2,26)$. For example, Purdy et al. (27) used images from the National Aeronautics and Space Administration's Geostationary Operational Environmental Satellite to track the movement of Saharan dust across the Atlantic as a surrogate (9) for the possible corresponding transport of sugarcane rust urediniospores from the Cameroons to the Dominican Republic. From there, backward air parcel trajectory analysis was used to track the introduction of the rust into Florida. There are other similar reports of transoceanic and continental transport of fungal spores and microbes, together with other particulate matter $(10,17,26)$. Although atmospheric wet deposition of ASR spores (DNA) was observed in Minnesota and South Dakota, the disease was not reported in those states during 2005. PCR does not distinguish live and dead spores. However, past studies with the cereal rusts show that urediniospores remain viable during long-range atmospheric transport from Texas to the upper Midwestern states (28). To our knowledge, there are no data that would suggest that ASR urediniospores would behave differently. Therefore, the absence of ASR disease in Minnesota and South Dakota during 2005 may be due to insufficient inoculum density or potential or to unfavorable moisture and temperature conditions that occurred during the 7-day period following spore deposition. Infection, disease development, and sporulation are favored by prolonged periods of leaf wetness accompanied by temperatures of 15 to $27.8^{\circ} \mathrm{C}$. Temperatures above or below this range retard disease development. Moisture, as rain or dew, favors disease development once infection has taken place $(12,16)$.

Moderate to severe drought conditions were present throughout western South Dakota, including the Cottonwood site, following the detection of ASR spores (DNA) and precipitation occurred only once during the 7 days after 26 July (20). Daily relative humidity was $<30 \%$ during daylight hours and average high temperatures were within $1^{\circ}$ of the 20-year normal of $30.5^{\circ} \mathrm{C}$ at Cottonwood. Similarly, there was no precipitation at Lamberton, MN during the 7-day period following 26 July. Daily high and average temperatures were below the 20-year norm for that area of the state. Average daytime relative humidity was $<60 \%$ between 8:00 A.M. and 8:00 P.M. (18). Overall, these environmental conditions do not favor ASR disease development.

Nevertheless, the characteristics of atmospheric transport and wet deposition in the Midwest, with Texas serving as the main initial source region for the ASR spores, are consistent with observations from other studies on cereal rusts (28). Similarly, long-range atmospheric transport of particulate sulfate and nitrate across the central plains and deposition in Minnesota by precipitation also has been reported (14).

\section{CONCLUSIONS}

ASR urediniospores (DNA) were detected in rain samples collected at NADP/NTN sites in Minnesota, Missouri, and South Dakota during late July 2005. Results of back trajectories for the rain events at these sites show that the most likely source areas were east-central and southern Texas, Louisiana, and Mississippi. The ASR spores (DNA) in an early July sample from a north-Texas NADP/NTN site appear to have originated from southern Texas or the YP in Mexico. During the 2005 growing season, ASR was reported in Texas, Louisiana, and Mississippi (31). In contrast, the disease has not been reported in Minnesota, Missouri, or South Dakota. The underlying reasons require further investigation. Similarly, the disease has not been reported from the YP, warranting our attention regarding the importance of the local alternative hosts in that region as sources of fungal inoculum. Atmospheric wet deposition of ASR spores at none of the sites in this study was associated with any severe weather conditions. Overall, these results are consistent with known yearly and seasonal synoptic meteorological processes in the continental United States and with the previous observations of the spread of cereal rust from the southern to the upper Midwestern states.

\section{ACKNOWLEDGMENTS}

The authors gratefully acknowledge the National Oceanic and Atmospheric Administration Air Resources Laboratory for provision of the HYSPLIT transport and dispersion model and for the READY website (22). Partial support for this work was provided by the United States Department of Agriculture-Agricultural Research Service (cooperative agreement 58-3640-5-137). The National Atmospheric Deposition Program is a State Agricultural Experiment Station project, entitled National Research Support Project 3: A Long-Term Monitoring Program in Support of Research on the Effects of Atmospheric Chemical Deposition. Support is received through the United States Department of Agriculture-Cooperative State Research, Education, and Extension Service (cooperative agreement 2002-39138-11964). Support also was provided by the Minnesota Legislature through the Minnesota Rapid Agricultural Response Fund.

\section{LITERATURE CITED}

1. Agrios, G. N. 2005. Plant Pathology. 5th ed. Elsevier Academic Press, Boston.
2. Aylor, D. E. 1986. A framework for examining inter-regional aerial transport of fungal spores. Agric. For. Met. 38:263-288.

3. Bluestein, H. 1992. Synoptic-Dynamic Meteorology in Midlatitudes. Oxford University Press, Oxford.

4. Dossett, S. R., and Bowersox, V. C. 1999. National Trends Network Site Operation Manual. National Atmospheric Deposition Program Office at the Illinois State Water Survey. NADP Manual 1999-01. Champaign, IL.

5. Draxler, R. 2003. Evaluation of an ensemble dispersion calculation. J. App. Meteor. 42:308317.

6. Draxler, R., and Hess, G. D. 2004. Description of the HYSPLIT 4 Modeling System. NOAA Technical Memorandum ERL ARL-224, June.

7. Finlayson-Pitts, B. J., and Pitts, J. N. 1999. Chemistry of the Upper and Lower Atmosphere. Academic Press, New York.

8. Frederick, R. D., Snyder, C. L., Peterson, G. L., and Bonde, M. R. 2002. Polymerase chain reaction assays for the detection and discrimination of soybean rust pathogens Phakopsora pachyrhizi and P. meibomiae. Phytopathology 92:217-227.

9. Griffin, D. W., Kellogg, C. A., Garrison, V. H., Lisle, J. T., Borden, T. C., and Shinn, E. A 2003. Atmospheric microbiology in the northern Caribbean during African dust events. Aerobiologia 19:143-157.

10. Griffin, D. W., Kellog, C. A., Garrison, V. H. and Shinn, E. A. 2002. The global transport of dust. Am. Sci. 90:228-235.

11. Isakeit, T., Miller, M. E., Saldana, R., Barnes, L. W., McKemy, J. M., Palm, M. E., Zeller, K. A., DeVries-Paterson, R., and Levy, L. 2006. First Report of Rust Caused by Phakopsora pachyrhizi on Soybean and Kudzu in Texas. Plant Dis. 90:971

12. Kochman, J. K. 1979. The effect of temperature on development of soybean rust (Phakopsora pachyrhizi). Aust. J. Agric. Res. 30:273277.

13. Krupa, S. V., Lodge, J. P., Jr., Nosal, M., and McVehil, G. E. 1987. Characteristics of aerosol and rain chemistry in north central USA Pages 121-128 in: Acidic Rain: Scientific and Technical Advances. Selper Ltd., London.

14. Krupa, S. V., and Nosal, M. 1999. Rainfall composition in Minnesota: Integrating the chemistry, synoptic meteorology and numerical modeling. Environ. Pollut. 104:477-483.

15. Marchetti, M. A., Uecker, F. A., and Bromfield, K. R. 1975. Uredial development of Phakopsora pachyrhizi in soybeans. Phytopathology 65:822-823.

16. Melching, J. S., Dowler, W. M., Koogle, D. L. and Royer, M. H. 1989. Effect of duration, frequency, and temperature of leaf wetness periods on soybean rust. Plant Dis. 73:117-122.

17. Mims, S. A., and Mims, F. M., III. 2004. Fungal spores are transported long distances in smoke from biomass fires. Atmos. Environ. 38:651-655.

18. Minnesota Climatology Working Group. 2005. Agricultural climate: Monthly temperature and precipitation summary tables. University of Minnesota, St. Paul.

19. National Atmospheric Deposition Program. 2005. National atmospheric deposition program 2004 annual summary. NADP Data Report 2005-01. Illinois State Water Survey, Champaign.

20. National Oceanic and Atmospheric Administration. 2005. The drought monitor. National Drought Mitigation Center, Lincoln, NE.

21. National Oceanic and Atmospheric Administration - Air Resources Laboratory. 2006. HYSPLIT program with archived data. NOAA Air Resources Laboratory, Silver Spring, MD.

22. National Oceanic and Atmospheric Administration - Air Resources Laboratory. 2006. The Real-Time Environmental Applications and 
Display System (READY). NOAA Air Resources Laboratory, Silver Spring, MD.

23. NRC (National Research Council, US). 1983. Acidic Deposition. Atmospheric Processes in Eastern North America. National Academy Press, Washington, DC.

24. Ono, Y., Buritica, P., and Hennen, J. 1992. Delimitation of Phakopsora, Physopella, and Cerotelium and their species on Leguminosae. Mycol. Res. 96:825-850.

25. Pivonia, S., and Yang, X. B. 2004. Assessment of the potential year-round establishment of soybean rust throughout the world. Plant Dis. 88:523-529.
26. Prospero, J. M., Blades, E., Mathison, G., and Naidu, R. 2005. Interhemispheric transport of viable fungi and bacteria from Africa to the Caribbean with soil dust. Aerobiologia 21:119.

27. Purdy, L. H., Krupa, S. V., and Dean, J. L. 1985. Introduction of sugarcane rust into the Americas and its spread to Florida. Plant Dis. 69:689-693.

28. Roelfs, A. P. 1985. Epidemiology in North America. Pages 403-434 in: The Cereal Rusts: Diseases, Distribution, Epidemiology and Control. Vol. II. Academic Press, New York.

29. Roelfs, A. P., and Long, D. L. 1987. Puccinia graminis development in North America during 1986. Plant Dis. 71:1089-1093.

30. Schneider, R. W., Hollier, C. A., Whitam, H. K., Palm, M. E., McKemy, J. M., Hernandez, J. R., Levy, L., and DeVries-Paterson, R. 2005. First report of soybean rust caused by Phakopsora pachyrhizi in the continental United States. Plant Dis. 89:774.

31. United States Department of AgricultureAnimal Plant Health Inspection Service (USDA-APHIS). 2006. Pest information platform for extension and education. Chronology of positive detections of soybean rust. Website for reporting of soybean rust in the U.S. 